\title{
The Effect of Leadership Behaviours on the Change Process in Healthcare Organisations in Saudi Arabia
}

\author{
Mohammad F. Alharbi ${ }^{1}$ \\ ${ }^{1}$ Department of Health Administration, College of Public Health and Health Informatics, Qassim University, \\ Qassim, KSA \\ Correspondence: Mohammad Alharbi, Health Administration, College of Public Health and Health Informatics, \\ Qassim University, Qassim, Saudi Arabia. E-mail: moh.alharbi@qu.edu.sa
}

\author{
Received: March 16, 2018 Accepted: April 26, 2018 Online Published: April 28, 2018 \\ doi:10.5539/gjhs.v10n6p77 URL: https://doi.org/10.5539/gjhs.v10n6p77
}

\begin{abstract}
Objective: The purpose of this empirical study was to explore and determine the influence of leadership behaviors on the organisational change process in healthcare organisations in the Kingdom of Saudi Arabia.

Methods: Primary data were collected from a sample of 272 employees in hospitals in the Al-Qassim region. The study used a self-administered questionnaire to examine the role of leadership behaviors (task-, relations-, and change-oriented leadership behaviors) on the organisational change process in healthcare organisations. Cross-sectional data were analyzed using SPSS.
\end{abstract}

Results: Positive and significant relations were found between leadership behaviors and the organisational change process contributed $54 \%$ of the variation in the dependent variable $\left(\mathrm{R}^{2}=0.54\right)$.

Conclusions: The findings of this research are highly significant, as they can give managers and organisational leaders a more profound insight into the behaviors and practices required to improve healthcare organisations' performance during implementation of the change process.

Keywords: leadership behaviours, task behaviour, relation behaviour, change behavior, change process, healthcare organisations, saudi healthcare system

\section{Introduction}

The key objective of any healthcare organisation is to give sick patients safe, high-quality care. They also must maintain financial sustainability, adhere to ethical guidelines, and provide community services (Kimber, Barwick, \& Fearing, 2012). The healthcare system is undergoing continuous change worldwide tody. It is intricate and fluctuating, and subject to various challenges associated with providing the community with quality, cost-effective care (Jordan, Werner, \& Venter, 2015). This also applies to Saudi Arabia, which recently has established a new agenda to enhance healthcare services by 2030 through the Vision programme.

This new and ambitious programme was launched in Saudi Arabia in 2016. Its primary purpose is to address three key topics, creating a vibrant society, an ambitious nation, and a thriving economy (The government of Saudi Arabia, 2016a). To accomplish this, an interim development plan referred to as "the National Transformation Program 2020" was developed. In this plan, the strategic objectives for all economic sectors were outlined, including those for the healthcare industry. A critical aspect of the National Transformation Program 2020 is to introduce reforms to the healthcare sector (The government of Saudi Arabia, 2016b). The plan highlights the need to strengthen the healthcare system, promote effective healthcare, control non-communicable and communicable diseases and health safety, and enhance healthcare partnerships. All of these factors are designed to improve healthcare services by redefining and restructuring the way the sector is organised and managed. The NTP 2020 strategic plans also focus on enhancing the processes of monitoring and assessing the Saudi healthcare system through the use of patient-friendly systems. The strategy also intends to promote private sector investment in sectors that government sources financed previously (The Saudi Arabian General Investment Authority, 2016).

During periods of complex change, as is the case with the Saudi Health Sector Change Plan, healthcare organisations must adapt to organisational change to fulfill their objectives. Nonetheless, organisational change is difficult to implement (Carter, Armenakis, Feild, \& Mossholder, 2013). This is particularly relevant to public organisations, as their environmental and structural features arguably make the implementation of changes even 
more difficult. Antwi and Kale (2014) asserted that healthcare organisations are complicated because they consist of various different professions, including doctors, nurses, administrators, and pharmacists, all of whom have competing interests, opinions, and time constraints.

Organisational change undoubtedly causes stress before, during, and after it is implemented. Change often generates an environment of conflict, resistance, and discomfort. This is the case even when the change is considered positive. As change requires adaptation to an unknown situation, it can be chaotic and dramatic (Bovey \& Hede, 2001). Therefore, it is crucial to reinforce organisational change through knowledgeable leadership behavior, as this can allow the change to fulfill its positive, long-term objectives. An effective manager can address a situation and make the relevant sacrifices at the beginning of the managerial procedure to accomplish the organisation's long-term objectives (Smollan, 2015). Ultimately, it is crucial that managers adopt a holistic approach in their leadership behavior, despite the fact that each management professional has different ways of applying leadership behavior and influencing staff. In the healthcare industry, administrative operations and care provision are vastly different, and thus, leadership activities may be confusing. It is particularly important to note that the backgrounds, experiences, and understanding of managerial staff oppose those of care providers frequently (Smollan, 2015).

In accordance with the assumption that organisational changes in different healthcare settings may be achieved by effective leadership, this study was designed to explore the role leadership behavior and skills play, and the extent to which they may optimize the changes taking place in the Saudi healthcare system. To date, there has been little research on this topic. Thus, this study was intended to fill this research void and determine whether leadership behavior affects organisational change in healthcare systems. The research findings are highly significant, as they can give managers and other organisational leaders a more profound insight into the practices required to improve the performance of healthcare organisations during periods of change. Secondly, the information may provide a background for strategic changes in healthcare service operations. Thirdly, the findings will improve authorities' understanding of the changes required within the healthcare sector. Lastly, the research will make a valuable contribution to the lack of empirical research by concentrating on organisational changes within the Saudi healthcare system.

\section{Literature Review}

\subsection{Organisational Change in Healthcare}

Many efforts have been made worldwide to redevelop healthcare organisations to improve their effectiveness and efficiency. The powerful forces that affect these organisations, including advancements in technology, competition, and social trends, have led to change that is both unavoidable and ubiquitous (Shah, 2011; Holton \& Brenner, 2015). More emphasis is being placed on change as a key factor in motivating organisational success, and this, in turn, has led to organisational and academic research about change practices, methodologies, and results (Friedman, 2005; Ford \& Gioia, 2000; Jørgensen, Owen, \& Neus, 2008). Recent research also has investigated change as a variable in developing an organisation's competitive advantage. Thus, to achieve success, organisations must respond to changes within their setting. Implementing integrated services and developing collaborations among healthcare organisations currently are the key focus in the field (Casebeer, Popp, \& Scott, 2009; Collins, Hewson, Munger, \& Wade, 2010; Grenier, 2011; Singh, Mathiassen, Stachura, \& Astapova, 2010). However, implementing radical changes within an organisation or system is highly challenging, especially in healthcare organisations and systems, as typically, they are pluralistic in nature. There is continued interest in the factors that facilitate change and how to implement it successfully in healthcare organisations and systems (Greenhalgh, Robert, Macfarlane, Bate, \& Kirriakidou, 2004; Longo, 2007; Ridder, Doege, \& Martini, 2007).

Change management can be described as a process that involves the consistent renewal of an organisation's direction, structure, and ability to meet the ever-changing requirements of internal and external customers (Moran \& Brightman, 2001). Hussan (2015) described change as an ever-present aspect in organisational life, both at the strategic and operational levels. As a vast number of healthcare organisations operate in the government sector, their leaders face several unique challenges. The key challenge in organisational change is to improve an organisation's capacity to respond efficiently to a changing environment and shape that environment. It is impossible to implement change in any organisation unless it and its workers can adjust their values and norms, as changes in beliefs and actions are crucial in accomplishing fundamental changes. The more that the changes proposed affect and contrast with the organisation's existing values and culture, the more difficult it they are to implement (Beer, 2002; Voelpel, Leibold, \& Mahmoud, 2004).

The change process includes a wide range of features, primarily quality change communication and employee participation, procedural justice, principal support, and change management competency (Holt, Armenakis, Feild, 
\& Harris, 2007; Amiot, Terry, Jimmieson, \& Callan, 2006; Shum, Bove, \& Auh, 2008). Employee participation and quality change communication are the primary features in the change process, and the former gives employees a sense that they are involved in the change and can control it, while the latter underscores the reasons why organisational change is necessary and articulates the vision underlying that change effectively (Oreg, 2006; Holt, Armenakis, Feild, \& Harris, 2007; Qian \& Daniels, 2008; Ertürk, 2008).

In employee participation, superiors allow their subordinates to take part in making decisions (Sagie, Elizur, \& Koslowsky, 1995). In general, change is accepted, embraced more eagerly, and perceived favourably if the change recipients are engaged more actively in bringing about that change (Holt, Armenakis, Feild, \& Harris, 2007; Amiot, Terry, Jimmieson, \& Callan, 2006; Sagie, Elizur, \& Koslowsky, 1995; Wanberg \& Banas, 2002; Coyle-Shapiro, 2002).

High quality change communication includes information about employee concerns that is precise, timely, and comprehensive, and that makes the change process more comprehensible and easier to cope with (Miller \& Monge, 1986; Miller, Johnson, \& Grau, 1994). Indeed, the more information provided, and the more accurate and reliable it is during the change process, the more the change is accepted widely (Wanberg \& Banas, 2002; Lewis, 1999; Axtell et al., 2002). Further, change-related communication made employees less anxious and uncertain, increased their trust of management, and reduced their likelihood to quit. On the other hand, absence of communication during change results in lack of certainty and causes problems for the change recipients as the change is implemented (Coyle-Shapiro, 2002; Miller \& Monge, 1986; Schweiger \& Denisi, 1991). Employees who are informed about change and what it involves timely and accurately, and who are allowed to take part in its implementation accept change more readily (Oreg, 2006).

\subsection{Leadership Behaviours}

Leadership is difficult to define because it is such a complex construct. The reasons that it is so elusive is because so many different definitions, theories, and processes have been developed over the years (Levy, 2006).

Northouse (1997) described it as a process that requires influence. He added that leadership occurs in a group setting and focuses on achieving specific goals.

It can be argued that robust leadership inspires a team of colleagues to explore creative concepts. This is a great strength of leadership and helps reorient attention to excellence and efficiency rather than quantity. Excellence and efficiency help an organisation achieve a competitive advantage and are significant factors in its sustainability and success.

Leadership enables qualitative change by altering workers' perspectives (Bass \& Avolio, 1999). Further, leadership is crucial in introducing innovative practices in an organisation effectively, and this is especially applicable to the healthcare industry (Edmondson, Bohmer, \& Pisano, 2001; Edmondson, 2003). However, because the leader's actions tend to occur within the organisation's contextual setting, congruence in organisational strategies on all levels can be facilitated by effective leadership and ultimately increases the chances that an organisation will implement and sustain change effectively (Parry \& Proctor-Thomson, 2003; Schuller, Kash, Edwardson, \& Gamm, 2013).

Most leadership research has concentrated on leaders' personal traits by exploring the relation between leadership behavior and numerous dimensions of its effectiveness (Yukl, 2006; B. M. Bass \& R. Bass, 2008). According to Robbins and Judge (2007), a vast amount of research on leadership behavior derived from pioneering studies and programs at the Ohio State University and the University of Michigan. Given the diversity of views in research on leadership behavior, we chose to use the work of Yukl, Gordon, and Taber (2002) and Yukl (2008).

Yukl et al. (2002) created a hierarchical framework with which they were able to determine which leadership behavior categories are the most significant. Further, the authors carried out work in 2002 that reviewed a half-century of leadership behavior studies conducted largely in America. In this research, they concluded that leaders must be able to demonstrate effectively twelve behaviors that are crucial to leaders' success; these may be categorized into three groups: task, relationship, and change-oriented. Yukl et al. (2002) suggested that effective leadership behavior relies on task-related behavior (being able to use personnel and resources effectively to achieve a task), relationship behavior (behavior associated with developing trust and cooperation in the organisation) and change behavior (enhancing innovation and adaptation).

Task-oriented behaviors focus predominantly on achieving tasks in the most reliable and efficient way. These behaviors include making interim plans, checking responsibilities and important objectives, solving problems rapidly, and monitoring procedures and achievements that enable assignments to be accomplished effectively and reliably (Yukl et al., 2002). Successful task-oriented leaders are able to create organisational processes and systems 
that encourage individuals to embrace new work patterns (Bass \& Stogdill, 1990). Research has indicated that there is a positive correlation between task-oriented behaviors and numerous outcomes. These include fulfilment at work, loyalty to the organisation, enthusiasm, organisational achievement, and leaders' popularity and efficiency (Dale \& Fox, 2008; Amabile, Schatzel, Moneta, \& Kramer, 2004).

Secondly, according to Yukl (2006), leadership behaviour based on relationships emphasises the importance of developing such relationships, improving confidence, working as a team, and enhancing the sense of fulfilment at work and loyalty to the organisation. Key concepts in this approach are being consultative, encouraging autonomy, sustaining, nurturing, recognizing, and acting as a powerful role model.

Relationship-oriented skills include behaviors that encourage cooperation and interaction between organisational members and develop a supportive social climate. They also include the promotion of management practices that can guarantee equal treatment of all those involved in the organisation (Bass \& Stogdill, 1990). Research indicates that there is a positive relation between relationship-oriented behaviors and various outcomes, including work satisfaction, organisation commitment, and motivation (Judge, Piccolo, \& Ilies, 2004; Watson \& Hoffman, 2004; Schriesheim, Neider, \& Scandura, 1998; Rafferty \& Griffin, 2006).

A third approach focuses on change-oriented behaviour. This approach emphasises improving tactical decision-making, innovation, and flexibility, and adapting to environmental change. It also is important when making significant operational changes to services, products, and processes to acquire commitment to those changes on the part of all team members (Yukl et al., 2002). On the whole, research has indicated that there is a positive relation between these change-oriented behaviors and numerous results that enhance organisational change, including positive work attitudes and the effectiveness of managerial activities. This is because such behaviors show the extent to which a leader is committed to the change process (Gil, Rico, Alcover, \& Barrasa, 2005; Barling, Weber, \& Kelloway, 1996; Kirkpatrick \& Locke, 1996).

\subsection{Relation Between Leadership Behaviours and Organisational Change Process}

There are many reasons why organisational changes may be needed. These include a need to adapt to contextual changes, introduce new technologies, and funding cuts (Edmondson et al., 2001; Choi, Holmberg, Löwstedt, \& Brommels, 2011). Organisations cannot change by themselves; instead, it is the organisation's members who make the changes. In hierarchical settings like hospitals, the leadership plays a fundamental role in initiating and organizing changes (Choi et al., 2011; Tucker \& Edmondson, 2003).

By (2005) asserted that change is a natural occurrence in organisational life, both on the strategic and operational levels. Therefore, it is challenging to everyone involved. Gill (2003) stressed that the change process must be managed well by effective leaders to be successful, and this is achieved through efficient planning, organisation, and management. If these are not achieved, the change process will fail, which has been demonstrated in a wealth of studies on organisational change. Organisational change has been studied extensively in recent years, and the studies have highlighted its importance (Fugate, Kinicki, \& Prussia, 2008; Caldwell, Herold, \& Fedor, 2004; Rafferty \& Griffin, 2006; Oreg, 2006). In addition, the features of the process help employees embrace change better, according to the presently dominant perspective on change management (Oreg, 2006; Dent \& Goldberg, 1999).

According to the findings of recent studies, the outcomes of change programs usually are suboptimal, and there is significant evidence that such programs frequently end in failure or have adverse implications (Beer, Eisenstat, \& Spector, 1990). Gill (2003) identified ineffective leadership as the causative factor that explains such high failure rates. The purpose of leadership is to promote change among its recipients, and hence, it should be correlated positively with the implementation of change. Direct supervisors who adopt behaviours of change leadership can foster two change process features that encourage change acceptance, employee participation and high-quality change information in the process of implementing change (Rafferty \&_Restubog, 2010; Devos, Buelens, \& Bouckenooghe, 2007; Walker, Armenakis, \& Bernerth, 2007). The main features of change leadership Herold, Fedor, Caldwell, and Liu, (2008) identified were change-related communication and participation in the change process. Enhancing employees' awareness of the scope and time course of change implementation also is important. Effective communication improves certainty and clarity about the change to be implemented (Van Dam, Oreg, \& Schyns, 2008), and employees are less likely to resist change and more willing to cooperate if leadership demonstrates relationship-oriented behaviour. During change implementation, leadership should prioritise close cooperation with employees and should be committed to transparent action, communication, and sharing. Thus, by adopting a behavioural approach to leadership, managers can gain employees' trust and make them more likely to accept change by sharing information effectively and timely (Yukl et al., 2002; Yukl, 2008). 
Trust is developed within an organisation by sharing high quality information, as the very act of sharing shows that the information recipients are trusted, which fosters trust in return. In the context of a health organisation, an instrumental and value-oriented attitude is associated closely with trust. However, building trust is no easy task. While implementing change, it is essential for leadership to be confident and able to convey a vision and manage subordinates to achieve that vision (Yukl et al., 2002; Albrecht \& Andreetta, 2011).

Employees' motivation is enhanced significantly by leadership's relationship-oriented behaviour that gives them a sense that their input is recognised and valued, as well as that their work actually contributes to organisational development. In turn, employees who feel they are contributing to organisational success are more motivated to make greater efforts to implement the change process (Yukl et al., 2002).

Task-oriented behaviour is another form of leadership behaviour that prioritises a particular task or set of tasks and related processes and makes it easier to comprehend task specifications, processes, and collections of relevant information (Derue, Nahrgang, Wellman, \& Humphrey, 2011; Burke et al., 2006). Thus, employees' motivation is influenced favourably and potently by a leadership plan that is directional and instructional (Lee, 2005). According to the findings of previous studies, the efficiency of the manager-employee relationship depends on the ongoing practice of the key managerial functions included in task-oriented leadership behaviour, which are intended to encourage employees to act similarly, and thus shape behavioural attitudes in the workplace (Derue et al., 2011; Tabernero, Chambel, Curral, \& Arana, 2009).

Leaders who adopt task-oriented leadership typically formulate straightforward work schedules that specify requirements and deadlines clearly, and thus uphold high standards effectively. Because of the high level of organisation and emphasis on deadlines, this type of leadership is useful particularly for employees who require structure and have trouble with time management (Yukl et al., 2002; Yukl, 2008). The main activities associated with task-oriented leadership are planning, scheduling work, coordinating operations, providing information required, and implementing demanding, yet attainable task goals. Further, to ensure efficient communication about change outcomes between managers and employees, it is essential to monitor, share knowledge, and provide feedback and information. Further, successful leaders also have to take into account task requirements and employees' traits when taking action (Burke et al., 2006; Tabernero et al., 2009).

Organisations are not simply institutions that perform tasks, but also are social institutions. Therefore, to guarantee high organisational performance to implement the change process, whilst at the same time ensuring that organisational members, units, and processes are cohesive and integrated properly, a series of general task-based, relationship-oriented, and change-oriented behaviors, respectively, must be adopted (House \& Aditya, 1997). In accordance with the argument presented above, this research proposed the following hypotheses:

Hypothesis 1: Leadership behaviors will be related positively to the organisational change process in healthcare organisations in Saudi Arabia.

Hypothesis 1a: Change-oriented leadership behaviors will be related positively to the organisational change process in healthcare organisations in Saudi Arabia.

Hypothesis 1b: Relationship-oriented leadership behaviors will be related positively to the organisational change process in healthcare organisations in Saudi Arabia.

Hypothesis 1c: Task-related leadership behaviors will be related positively to the organisational change process in healthcare organisations in Saudi Arabia.

\section{Methods and Materials}

\subsection{Research Design}

A quantitative approach was used in this study. The survey design was cross-sectional and involved the use of a questionnaire the respondents completed to explore their opinions (Cooper \& Schindler, 2003). The target population for this research consisted of 9737 appropriate employees from all 18 hospitals in the Al-Qassim region of Saudi Arabia (Ministry of Health, 2016). For the purposes of this study, the Yamane (1967) formula was used to select the sample size for the study, which brought the sample size to 370 respondents:

$$
n=\frac{N}{1+N *(e)^{2}}
$$

Data were collected over a period of six weeks beginning December 10, 2017. Of the 407 self-administered questionnaires distributed, 285 were completed and returned, 13 of which were invalid. Therefore, data were 
analyzed based on responses received from 272 respondents (response rate, $70 \%$ ).

\subsection{Measurement of Variables}

All items in the questionnaire were adopted from well-known measures used in previous studies that pertained to the key variables of this research. Leadership behavior was the independent variable and included the three dimensions above: task-, relationship-, and change-oriented behaviors.

To measure this independent variable, we used a scale that included six items for each of the three groups of leadership behaviors that were adapted based on Yukl's study (1999). The dependent variable of the organisational change process included two dimensions: quality change communication that was measured using a seven-item scale adapted from Bordia, Hunt, Paulsen, Tourish, and DiFonzo's study (2004). The second dimension was employees' participation, which was measured using a three-item scale adapted from Lines, Selart, Espedal, and Johansen's work (2005). Two bilingual experts were asked to check the comparability of the English and Arabic versions of the questionnaire. Any discrepancies remaining were resolved by a third bilingual expert, who translated the Arabic version back into English. After receiving ethical approval, the Arabic version of the questionnaire was sent to the hospitals with a cover letter that described the objectives of the study.

The respondents were asked to give their opinions on a variety of subjects using a 5-point Likert scale that ranged from 1 (strongly disagree) to 5 (strongly agree). Employees were invited to evaluate their direct supervisor's behavior (in the case of leadership behaviors) and their perceptions of the organisational change process in their organisations (in the case of the organisational change process).

\subsection{Data Analysis}

SPSS v. 21.0 (IBM Corp., Armonk, NY, USA) was employed for the analysis and the demographic features were identified using descriptive statistics. All aspects and variables were tested for reliability using Cronbach's alpha. Further, Exploratory Factor Analysis (EFA) was applied to all variables and the relation between variables was explored using correlation analysis. Finally, the study hypotheses were tested using linear regression analysis.

\section{Results}

\subsection{Demographic Characteristics}

The respondents' demographics are presented in Table 1. The respondents were diverse with respect to age, nationality, gender, marital status, educational background, and duration of current job.

Table 1. Respondents' Sociodemographic Variables

\begin{tabular}{llll}
\hline Variable & Category & Frequency & Percentage \\
\hline Nationality & Saudi & 234 & 86 \\
& Non-Saudi & 38 & 14 \\
\hline Gender & Male & 228 & 83.8 \\
& Female & 44 & 16.2 \\
\hline Age & Less than 20 years & 0 & 0 \\
& $20-30$ years & 79 & 29.0 \\
& $31-40$ years & 133 & 48.9 \\
& $41-50$ years & 47 & 17.3 \\
Marital Status & 51 years and above & 13 & 4.8 \\
& Single & 107 & 39.3 \\
& Married & 162 & 59.6 \\
& Divorced & 3 & 1.1 \\
\hline
\end{tabular}




\begin{tabular}{llll}
\hline Education Background & High School & 27 & 9.9 \\
& Diploma & 143 & 52.6 \\
& College Degree & 74 & 27.2 \\
& Master's & 9 & 3.3 \\
& PhD & 1 & .4 \\
& Other & 18 & 6.6 \\
\hline Duration of current job & Less Than One Year & 7 & 2.6 \\
& $1-5$ & 39 & 14.3 \\
& $6-10$ & 82 & 30.1 \\
& $11-15$ & 95 & 34.9 \\
& $16-20$ & 49 & 18.0 \\
& 21 and Above & 7 & 2.6 \\
\hline
\end{tabular}

\subsection{Reliability Test}

The internal consistency of the scale was evaluated with Cronbach's alpha. According to Nunnally (1978), if the alpha coefficient is greater than 0.70 , it is considered reasonably reliable.

The reliability tests of various dimensions are summarized in Table 2 with $\alpha>0.70$. The leadership behaviors oriented to task, relationship, and change, and the two dimensions of the organisational change process, quality of change communication and employees' participation measurements indicated that the Cronbach's alpha coefficients for all dimensions were greater than 0.70 .

Table 2. Reliability Results

\begin{tabular}{llll}
\hline Variables & Dimensions & No. of items & Cronbach's alpha \\
\hline Leadership behaviors & Task behaviors & 6 & 0.88 \\
& Relationship Behaviors & 6 & 0.89 \\
& Change behaviors & 6 & 0.88 \\
Organisational change process & Quality change communication & 3 & 0.87 \\
& Employees' participation & 3 & 0.86 \\
\hline
\end{tabular}

\subsection{Exploratory Factor Analysis}

EFA was performed on the task-, relationship-, and change-oriented leadership behaviors. EFA also was conducted on the organisational quality of change communication and employees' participation.

Table 3 shows the number of items for each dimension and presents the findings of the EFAs with respect to leadership behaviours and the organisational change process. The table provides the factor loadings of the five sub-dimensions for all items after each procedure. It is clear that there was no double loading or low factor loading $(<0.50)$, as the items' loading ranged from 0.52 to 0.87 .

As Table 3 shows, the Kaiser-Meyer-Olkin (KMO) test score was 0.86 for the factors measured. This indicates "meritorious adequacy" for the factor analysis (Hair, Anderson, Tatham, \& Black, 2006). The Bartlett Sphericity Value of 5030.67 also was significant $(p=0.00)$. Therefore, the factors employed met the standards required for factor analysis, and it was appropriate to use EFA to assess the relation between the factors used and the organisational change process. 
Table 3. Exploratory Factor Analyses

\begin{tabular}{|c|c|c|c|c|c|}
\hline \multirow{2}{*}{ Items } & \multicolumn{5}{|c|}{ Component } \\
\hline & 1 & 2 & 3 & 4 & 5 \\
\hline Relationship Behavior RB3 & \multicolumn{5}{|c|}{0.84} \\
\hline Relationship Behavior RB5 & \multicolumn{5}{|c|}{0.80} \\
\hline Relationship Behavior RB4 & \multicolumn{5}{|c|}{0.77} \\
\hline Relationship Behavior RB6 & \multicolumn{5}{|c|}{0.77} \\
\hline Relationship Behavior RB2 & \multicolumn{5}{|c|}{0.72} \\
\hline Relationship Behavior RB1 & \multicolumn{5}{|c|}{0.67} \\
\hline Quality Change Communication QC2 & \multicolumn{5}{|c|}{0.86} \\
\hline Quality Change Communication QC4 & \multicolumn{5}{|c|}{0.84} \\
\hline Quality Change Communication QC3 & \multicolumn{5}{|c|}{0.83} \\
\hline Quality Change Communication QC6 & \multicolumn{5}{|c|}{0.71} \\
\hline Quality Change Communication QC1 & \multicolumn{5}{|c|}{0.69} \\
\hline Quality Change Communication QC5 & \multicolumn{5}{|c|}{0.64} \\
\hline Quality Change Communication QC7 & \multicolumn{3}{|c|}{0.55} & & \\
\hline Change Behavior CB4 & \multicolumn{5}{|c|}{0.87} \\
\hline Change Behavior CB1 & & \multicolumn{4}{|c|}{0.83} \\
\hline Change Behavior CB2 & & \multicolumn{4}{|c|}{0.81} \\
\hline Change Behavior CB5 & & \multicolumn{4}{|c|}{0.71} \\
\hline Change Behavior CB3 & & \multicolumn{4}{|c|}{0.68} \\
\hline Change Behavior CB6 & & \multicolumn{4}{|c|}{0.52} \\
\hline Task Behavior TB3 & & & \multicolumn{3}{|c|}{0.86} \\
\hline Task Behavior TB2 & & & \multicolumn{3}{|c|}{0.83} \\
\hline Task Behavior TB6 & & & \multicolumn{3}{|c|}{0.78} \\
\hline Task Behavior TB1 & & & \multicolumn{3}{|c|}{0.77} \\
\hline Task Behavior TB5 & & & \multicolumn{3}{|c|}{0.76} \\
\hline Task Behavior TB4 & & & \multicolumn{3}{|c|}{0.68} \\
\hline Employee Participation EP2 & & & & & 0.81 \\
\hline Employee Participation EP3 & & & & & 0.70 \\
\hline Employee Participation EP1 & & & & & 0.68 \\
\hline Percentage of variance explained (\%) & \multicolumn{5}{|c|}{66.67} \\
\hline Kaiser-Meyer-Olkin & \multicolumn{5}{|c|}{0.86} \\
\hline Bartlett's test of sphericity approx. $\mathrm{Chi}^{2}$ & & & & & \\
\hline df & 37 & & & & \\
\hline Sig. & & & & & \\
\hline
\end{tabular}

\subsection{Correlation and Regression Analyses}

Correlation analysis is used to determine the direction and strength of the linear association between two variables (Pallant, 2013). Therefore, the association between the leadership behaviours and the organisational change process was assessed using Pearson's correlations of the employees' responses. A scatterplot indicated that the results were distributed normally and the Shapiro-Wilk's test showed that there were no outliers $(p>0.05)$. Table 4 provides a summary of the correlations. The table shows that leadership behaviors overall were correlated 
positively with the organisational change process, and the values of the correlation coefficient relative to the relations assessed between the variables overall was $0.68(p<0.01)$. Moreover, there was a positive relation between task-oriented behavior and organisational change. The correlation coefficient was $0.24(p<0.05)$. The results also indicated a relation between a relationship-oriented approach to leadership and the process of organisational change (see Table 4). The correlation coefficients for the two variables were $0.61(p<0.01)$.

Further, it is evident from Table 4 that change behavior was related to the organisational change process. The correlation coefficient was $0.63(p<0.01)$.

Table 4. Summary of Correlations of Variables

\begin{tabular}{|c|c|c|c|c|c|c|c|}
\hline Variables & & $\begin{array}{l}\text { Change } \\
\text { Process }\end{array}$ & $\begin{array}{l}\text { Leadership } \\
\text { Behaviours } \\
\text { Overall }\end{array}$ & $\begin{array}{l}\text { Task } \\
\text { Behavior }\end{array}$ & $\begin{array}{l}\text { Relationship } \\
\text { Behavior }\end{array}$ & $\begin{array}{l}\text { Change } \\
\text { Behavior }\end{array}$ & $\begin{array}{l}\text { Quality change } \\
\text { communication }\end{array}$ \\
\hline Change Process & $\begin{array}{l}\text { Pearson } \\
\text { Correlation }\end{array}$ & & & & & & \\
\hline $\begin{array}{l}\text { Overall Leadersh } \\
\text { Behaviours }\end{array}$ & $\begin{array}{l}\text { pPearson } \\
\text { Correlation }\end{array}$ & $0.68^{* *}$ & & & & & \\
\hline Task Behavior & $\begin{array}{l}\text { Pearson } \\
\text { Correlation }\end{array}$ & $0.24^{* *}$ & $0.52^{* *}$ & & & & \\
\hline $\begin{array}{l}\text { Relationship } \\
\text { Behavior }\end{array}$ & $\begin{array}{l}\text { Pearson } \\
\text { Correlation }\end{array}$ & $0.61^{* *}$ & $0.77^{* *}$ & 0.07 & & & \\
\hline Change Behavior & $\begin{array}{l}\text { Pearson } \\
\text { Correlation }\end{array}$ & $0.63^{* *}$ & $0.78^{* *}$ & $0.20^{* *}$ & $0.48^{* *}$ & & \\
\hline $\begin{array}{l}\text { Quality chan } \\
\text { communication }\end{array}$ & $\begin{array}{l}\text { ePearson } \\
\text { Correlation }\end{array}$ & $0.53^{* *}$ & $0.44^{* *}$ & $0.16^{* *}$ & $0.35^{* *}$ & $0.39^{* *}$ & \\
\hline $\begin{array}{l}\text { Employees' } \\
\text { participation }\end{array}$ & $\begin{array}{l}\text { Pearson } \\
\text { Correlation }\end{array}$ & $0.88^{* *}$ & $0.55^{* *}$ & $0.19^{* *}$ & $0.52^{* *}$ & $0.53^{* *}$ & 0.05 \\
\hline
\end{tabular}

Note. ${ }^{* *}$ Correlation is significant at the 0.01 level (2-tailed); ${ }^{*}$ Correlation is significant at the 0.05 level (2-tailed).

Linear regression analysis was conducted to assess specifically the degree to which leadership behaviours could explain each respondent's opinion of the organisational change process.

It is evident from Table 5 that the $\mathrm{R}^{2}$ in the leadership behaviours overall made an important $54 \%$ contribution to the variance in the organisational change process. Further, the analysis confirmed that leadership behaviours predicted the organisational change process significantly $\left(F_{d f}=103.36, p<0.00\right)$.

Table 5. Results of Linear Regression Analysis of Effect of Leadership Behaviours on the Organisational Change Process

\begin{tabular}{|c|c|c|c|c|c|c|c|c|}
\hline \multirow[t]{2}{*}{ Independent variable } & \multicolumn{2}{|c|}{ Model summary } & \multicolumn{2}{|c|}{ ANOVA } & \multicolumn{4}{|c|}{ Coefficient } \\
\hline & $\mathrm{R}^{2}$ & Sig F change & $\mathrm{F}$ & Sig & $\mathrm{B}$ & Beta & $t$ & Sig. \\
\hline Leadership Behaviours Overall & 0.54 & 0.00 & 103.36 & 0.00 & & & & \\
\hline Relationship Behavior & & & & & 0.28 & 0.40 & 8.35 & 0.000 \\
\hline Change Behavior & & & & & 0.34 & 0.42 & 8.60 & 0.000 \\
\hline Task Behavior & & & & & 0.11 & 0.13 & 3.08 & 0.002 \\
\hline
\end{tabular}

\section{Discussion}

The results of the literature review confirmed that organisational change in the healthcare field is of great importance and healthcare organisations must be oriented to future change and development (Collins et al., 2010; Casebeer et al., 2009; Greenhalgh et al., 2004; Singh et al., 2010). 
The nature of the business must progress, adopt changes, and develop in its ongoing operations. Repetition and routine in the field of leadership in healthcare is a major failure that is associated with many problems (Gill, 2003; Beer et al., 1990).

Although many studies have raised the question of the importance of leadership behavior in organisational change in the public sector, few are empirical (Kuipers et al., 2014). Fernandez and Bates (2007) emphasized that leaders' personal characteristics play a vital role during the process of change and must be considered when it is adopted.

This gave us the incentive to investigate the importance of leadership behaviors in this empirical study to determine the effect of its three dimensions on organisational change in healthcare in Saudi Arabia.

Theoretically, one of the most important strategic goals that healthcare leaders must achieve is managing change and development. Lead managers are expected to have leadership qualities and behavior that will influence staff and lead to better performance (Devos et al., 2007; Walker et al., 2007; Rafferty \& Restubog, 2010). A manager with outstanding leadership skills inspires staff and helps an organisation provide the most high quality healthcare services.

Leadership in healthcare works in the core operations, services, and production in the service and human resources sectors. This means that a leader's personality and personal skills and his/her psychology and behavior are central issues in the core processes of organisational change (Smollan, 2015). It is not necessary for a manager in the healthcare facility to be a doctor or even an individual with strong scientific proficiency, even in the field of management and leadership. It is only important to be a competent leader who employs high standards of conduct in managing and directing his/her employees, and in making the best decisions for the organisation $\mathrm{s} / \mathrm{he}$ manages.

Hence, this research was based on a theoretical and practical framework, and the results showed that leadership behavior is an important skill that affects positive and significant organisational change in healthcare facilities and contributed 54\% of the variation in organisational change in healthcare in Saudi Arabia. This finding is consistent with many studies of leadership behavior that have confirmed that it is one of the most important factors that affects planning, implementing, directing, and controlling organisational change (Herold et al., 2008; Martin, Sutton, Willars, \& Dixon-Woods, 2013; Battilana, Gilmartin, Sengul, Pache, \& Alexander, 2010; Packard, Patti, Daly, \& Tucker-Tatlow, 2012).

The results of this study also are consistent with a similar study by Aarons, Ehrhart, Farahnak, and Hurlburt (2015), who concluded that intervention is important in achieving change and assessing its leadership effects, and the results of their study confirmed that when leadership behaviors were positive, they improved employees' responses to implementing change. Pattilana et al.'s (2010) study also concluded that leaders' competence and ability and awareness of leadership behavior are important factors in organisational change.

Leadership behavior usually refers to a set of features and skills that a manager should have to be a leader manager. The leader manager is involved in the change process and is familiar with the details of the organisation's operations and therefore, is able to understand those processes and provide guidance during the change. Appropriate leadership behavior is that in which the manager is receptive to others' views and feedback from the employees and beneficiaries in his organisation, and also listens to the proposals and views of staff and makes decisions about change in a democratic manner that meets the needs and desires of beneficiaries.

In addition, the results showed that, when tested individually, all independent variables that represented leadership behaviors contributed significantly to the dependent variable, the organisational change process.

Further, the dimension of change behaviour was the independent variable represented most clearly with a Beta value of 0.42 . This indicated that there was a strong association between change behaviour and the organisational change process in healthcare in Saudi Arabia. Leadership that practices relevant change behaviors can enhance the features of the change process and help implement change (Walker et al., 2007; Devos et al., 2007).

According to Yukl et al. (2002), change-oriented leader behaviors comprise actions such as establishing and transmitting a clear vision of changes proposed, promoting creative ideas, and taking risks.

Herold et al. (2008) believe that the essential features of change leadership are that they support communication about the change and participation in the process, which also enhances staff awareness of the scope and timing of implementation of the change. Leadership that includes change-oriented behavior helps employees participate in the process of change by acquiring quality information from a charismatic leader who encourages innovation and their involvement in the application of change. Therefore, change processes require leadership that includes change-oriented behavior to facilitate and promote the change process.

Further, the results of this study showed that leadership's relationship-oriented behavior is related significantly and 
positively to the change processes in healthcare organisations in Saudi Arabia. This dimension was the second most important of the dimensions that represented the independent variables after change-oriented behavior and contributed to approximately $40 \%$ of the variation in the change process. This result is consistent with previous studies that have emphasized the importance of relationship-oriented behavior in organisations, because leaders support and involve staff by sharing information, such that they will be more likely subsequently to accept change (Wanberg \& Banas, 2002; Coyle-Shapiro, 2002; Miller et al., 1994).

The third sub-hypothesis posited that task-oriented leadership behavior is associated with the organisational change process in healthcare facilities in Saudi Arabia. The findings confirmed this association, and the analysis demonstrated that task-oriented behavior is associated positively with the organisational change process. Thus, this result is consistent with other studies that have emphasized that task-oriented leadership focuses on achieving organisational objectives by formulating a clear schedule that defines requirements and deadlines clearly and enhances the effectiveness of high performance standards (Yukl et al., 2002; Yukl, 2008).

Moreover, Yukl (2008) asserted that task-oriented behavior can improve the performance of individual subordinates and groups and contributes to increased productivity and elimination of unnecessary and costly activities.

Derue et al. (2011) regarded a task-oriented style of leadership as one that encompasses such activities as confirming that staff have detailed objectives, promoting defined roles within teams, and ensuring that there are clear criteria by which performance can be assessed.

This result also is consistent with those of Pattilana et al.'s (2010) study, who found that task-oriented behaviors have an effect on the organisational implementation of planned change associated with evaluation and mobilization activities.

The results of this study must be considered in the light of several limitations. The first is that the study was conducted in hospitals in only one region of Saudi Arabia, which restricts the ability to generalize the results. Future research should incorporate more regions to enhance the scope of the findings. The second is that the cross-sectional design allowed investigation of the factors only at one specific time. In view of the changing nature of human behaviour, a study with a longitudinal design would help confirm the findings. The final and most significant limitation is the common method bias that can result from the use of only one method to evaluate the relations.

\section{Conclusion}

Organisational change is imperative in businesses and public and government institutions. Conditions in the external environment change constantly, which is something that managers within organisations must follow to keep abreast of them and adapt to the new situations imposed on them. A country may be subject to economic changes or new trade laws that govern healthcare facilities. These changes must be reflected in organisational changes so an institution can continue its work, achieve its objectives, and provide services in the new environment.

Leadership behavior in organisational change cannot be ignored, as it provides the critical support for organisational change. When there are problems and a lack of leadership behavior among managers in healthcare facilities, the process of change becomes difficult, if not impossible. The owners of healthcare facilities and senior management should require leaders and executives in their organisations to demonstrate effective leadership behavior and skills to manage their businesses and institutions and provide services to patients and visitors. Even in public and government healthcare facilities, comprehensive quality plans and programs include the recruitment of an administrative staff with leadership skills to manage these facilities and provide the best services and patient care.

If one of the primary objectives of healthcare facilities is to provide better patient care, this care does not occur without management and leadership that support organisational change. Healthcare organisations should be interested in the studies and scientific experiments that have emphasised the need for leaders to adopt effective leadership behavior in the management of healthcare facilities. The literature reviewed and the results of this study emphasised that health facilities must adopt leadership behavior and organisational change. Even if it is accompanied by conflict and resistance, it should not prevent such change.

Although organisational change can face opposition from employees or healthcare facilities' users, it also can lead to the opposite, satisfaction and excitement on the part of staff, patients, stakeholders, and owners. The primary goal of change is to achieve an organisation's positive goals. These results may be achieved with the cooperation of the team, employees, and patients, and the response to this change may be protracted or difficult. Successful and 
sound leadership behavior supports organisational change and achieves it with the best results and the least amount of loss and protest. Even if the change is accompanied by new problems, appropriate leadership behavior can solve those problems and restore optimal organisational operation.

\section{Competing Interests Statement}

The author declares that there are no competing or potential conflicts of interest regarding the publication of this paper.

\section{References}

Aarons, G. A., Ehrhart, M. G., Farahnak, L. R., \& Hurlburt, M. S. (2015). Leadership and organizational change for implementation (LOCI): a randomized mixed method pilot study of a leadership and organization development intervention for evidence-based practice implementation. Implementation Science, 10(1), 11. https://doi.org/10.1186/s13012-014-0192-y

Albrecht, S. L., \& Andreetta, M. (2011). The influence of empowering leadership, empowerment and engagement on affective commitment and turnover intentions in community health service workers: Test of a model. Leadership in Health Services, 24(3), 228-237. https://doi.org/10.1108/17511871111151126

Amabile, T. M., Schatzel, E. A., Moneta, G. B., \& Kramer, S. J. (2004). Leader behaviors and the work environment for creativity: Perceived leader support. The Leadership Quarterly, 15(1), 5-32. https://doi.org/10.1016/j.leaqua.2003.12.003

Amiot, C. E., Terry, D. J., Jimmieson, N. L., \& Callan, V. J. (2006). A longitudinal investigation of coping processes during a merger: Implications for job satisfaction and organizational identification. Journal of Management, 32(4), 552-574. https://doi.org/10.1177/0149206306287542

Antwi, M., \& Kale, M. (2014). Change Management in Healthcare: Literature Review. Monieson Centre for Business Research in Healthcare, Queen's University. Retrieved from https://smith.queensu.ca/centres/monieson/knowledge_articles/files/Change\%20Management $\% 20 \mathrm{in} \% 20 \mathrm{He}$ althcare\%20-\%20Lit\%20Review\%20-\%20AP\%20FINAL.pdf

Axtell, C., Wall, T., Stride, C., Pepper, K., Clegg, C., Gardner, P., \& Bolden, R. (2002). Familiarity breeds content: The impact of exposure to change on employee openness and well being. Journal of occupational and organizational psychology, 75(2), 217-231. https://doi.org/10.1348/09631790260098596

Barling, J., Weber, T., \& Kelloway, E. K. (1996). Effects of transformational leadership training on attitudinal and financial outcomes: A field experiment. Journal of applied psychology, 81(6), 827-832. https://doi.org/10.1037/0021-9010.81.6.827

Bass, B. M., \& Bass, R. (2008). The Bass handbook of leadership: Theory, research, and managerial applications. (4th ed.). New York, NY: free Press.

Bass, B. M., \& Stogdill, R. M. (1990). Handbook of leadership (Vol. 11). New York: Free Press.

Bass, B., \& Avolio, B. (1999). Training full range leadership: A resource guide for training with the MLQ. Palo Alto, CA: Mind Garden.

Battilana, J., Gilmartin, M., Sengul, M., Pache, A. C., \& Alexander, J. A. (2010). Leadership competencies for implementing planned organizational change. The Leadership Quarterly, 21(3), 422-438. https://doi.org/10.1016/j.leaqua.2010.03.007

Beer, M. (2002). Building organizational fitness in the 21st century. Division of Research, Harvard Business School.

Beer, M., Eisenstat, R. A., \& Spector, B. (1990). Why change programs don't produce change. Harvard Business Review, 68(6), 158-166.

Bordia, P., Hunt, E., Paulsen, N., Tourish, D., \& DiFonzo, N. (2004). Uncertainty during organizational change: Is it all about control?. European Journal of Work and Organizational Psychology, 13(3), 345-365. https://doi.org/10.1080/13594320444000128

Bovey, W. H., \& Hede, A. (2001). Resistance to organizational change: the role of cognitive and affective processes. Leadership \& Organization Development Journal, 22(8), 372-382. Retrived from http://dx.doi.org/10.1108/01437730110410099

Burke, C. S., Stagl, K. C., Klein, C., Goodwin, G. F., Salas, E., \& Halpin, S. M. (2006). What type of leadership behaviors are functional in teams? A meta-analysis. The leadership quarterly, 17(3), 288-307. 
https://doi.org/10.1016/j.leaqua.2006.02.007

By, T. R. (2005). Organisational change management: A critical review. Journal of change management, 5(4), 369-380. https://doi.org/10.1080/14697010500359250

Caldwell, S. D., Herold, D. M., \& Fedor, D. B. (2004). Toward an understanding of the relationships among organizational change, individual differences, and changes in person-environment fit: a cross-level study. Journal of Applied Psychology, 89(5), 868-882. https://doi.org/10.1037/0021-9010.89.5.868

Carter, M. Z., Armenakis, A. A., Feild, H. S., \& Mossholder, K. W. (2013). Transformational leadership, relationship quality, and employee performance during continuous incremental organizational change. Journal of Organizational Behavior, 34(7), 942-958. https://doi.org/10.1002/job.1824

Casebeer, A., Popp, J., \& Scott, C. (2009). Positively deviant networks: what are they and why do we need them?. Journal of health organization and management, 23(6), 610-626. https://doi.org/10.1108/14777260911001635

Choi, S., Holmberg, I., Löwstedt, J., \& Brommels, M. (2011). Executive management in radical change -The case of the Karolinska University Hospital merger. Scandinavian Journal of Management, 27(1), 11-23. https://doi.org/10.1016/j.scaman.2010.08.002

Collins, C., Hewson, D. L., Munger, R., \& Wade, T. (2010). Evolving models of behavioral health integration in primary care. New York: Milbank Memorial Fund, 504. Retrieved from www.milbank.org/reports/10430EvolvingCare/EvolvingCare.pdf

Cooper, D. R., \& Schindler, P. S. (2003). Business Research Methods. (8th ed.). Boston: McGraw-Hill Irwin.

Coyle-Shapiro, J. A. (2002). Changing employee attitudes: the independent effects of TQM and profit sharing on continuous improvement orientation. The Journal of Applied Behavioral Science, 38(1), 57-77. https://doi.org/10.1177/0021886302381004

Dale, J., \& Fox, M. (2008). Leadership style and organizational commitment: Mediating effect of role stress. Journal of Managerial Issues, 20(1), 109-130.

Dent, E. B., \& Goldberg, S. G. (1999). Challenging "resistance to change". The Journal of applied behavioral science, 35(1), 25-41.DOI: 10.1177/0021886399351003

Derue, D. S., Nahrgang, J. D., Wellman, N. E. D., \& Humphrey, S. E. (2011). Trait and behavioral theories of leadership: An integration and meta analytic test of their relative validity. Personnel psychology, 64(1), 7-52. https://doi.org/10.1111/j.1744-6570.2010.01201.x

Devos, G., Buelens, M., \& Bouckenooghe, D. (2007). Contribution of content, context, and process to understanding openness to organizational change: Two experimental simulation studies. The Journal of social psychology, 147(6), 607-630. https://doi.org/10.3200/SOCP.147.6.607-630

Edmondson, A. C. (2003). Framing for learning: Lessons in successful technology implementation. California Management Review, 45(2), 34-54. https://doi.org/10.2307/41166164

Edmondson, A. C., Bohmer, R. M., \& Pisano, G. P. (2001). Disrupted routines: Team learning and new technology implementation in hospitals. Administrative Science Quarterly, 46(4), 685-716. https://doi.org/10.2307/3094828

Ertürk, A. (2008). A trust-based approach to promote employees' openness to organizational change in Turkey. International Journal of Manpower, 29(5), 462-483. DOI: 10.1108/01437720810888580

Fernandez, S., \& Pitts, D. W. (2007). Under what conditions do public managers favor and pursue organizational change?. The American Review of Public Administration, 37(3), 324-341. https://doi.org/10.1177/0275074006293467

Ford, C., \& Gioia, D. (2000). Factors influencing creativity in the domain of managerial decision making. Journal of Management, 26(4), 705-732. https://doi.org/10.1016/S0149-2063(00)00053-2

Friedman, T. (2005). The World is Flat. New York: Farrar Straus \& Giroux.

Fugate, M., Kinicki, A. J., \& Prussia, G. E. (2008). Employee coping with organizational change: An examination of alternative theoretical perspectives and models. Personnel Psychology, 61(1), 1-36. https://doi.org/10.1111/j.1744-6570.2008.00104.x

Gil, F., Rico, R., Alcover, C. M., \& Barrasa, A. (2005). Change-oriented leadership, satisfaction and performance 
in work groups: Effects of team climate and group potency. Journal of Managerial Psychology, 20(3/4), 312-328. https://doi.org/10.1108/02683940510589073

Gill, R. (2003). Change management--or change leadership?. Journal of change management, 3(4), 307-318. https://doi.org/10.1080/714023845

Greenhalgh, T., Robert, G., Macfarlane, F., Bate, P., \& Kyriakidou, O. (2004). Diffusion of innovations in service organizations: systematic review and recommendations. The Milbank Quarterly, 82(4), 581-629. https://doi.org/10.1111/j.0887-378X.2004.00325.x

Grenier, C. (2011). Structuring an integrated care system: interpreted through the enacted diversity of the actors involved the case of a French healthcare network. International journal of integrated care, 11(1), 1-15. https://doi.org/10.5334/ijic.526

Hair, J. F., Anderson, R. E., Tatham, R. L., \& Black, W. C. (2006). Multivariate data analysis. (6th ed.). New Jersey: Pearson Prentice Hall.

Herold, D. M., Fedor, D. B., Caldwell, S., \& Liu, Y. (2008). The effects of transformational and change leadership on employees' commitment to a change: A multilevel study. Journal of applied psychology, 93(2), 346-357. https://doi.org/10.1037/0021-9010.93.2.346

Holt, D. T., Armenakis, A. A., Feild, H. S., \& Harris, S. G. (2007). Readiness for organizational change: The systematic development of a scale. The Journal of applied behavioral science, 43(2), 232-255. https://doi.org/10.1177/0021886306295295

Holten, A. L., \& Brenner, S. O. (2015). Leadership style and the process of organizational change. Leadership \& Organization Development Journal, 36(1), 2-16. https://doi.org/10.1108/LODJ-11-2012-0155

Hossan, C. (2015). Applicability of Lewin's change management theory in Australian local government. International Journal of business and Management, 10(6), 53-65. https://doi.org/10.5539/ijbm.v10n6p53

House, R. J., \& Aditya, R. N. (1997). The social scientific study of leadership: Quo vadis?. Journal of management, 23(3), 409-473. https://doi.org/10.1016/S0149-2063(97)90037-4

Jack Walker, H., Armenakis, A. A., \& Bernerth, J. B. (2007). Factors influencing organizational change efforts: An integrative investigation of change content, context, process and individual differences. Journal of Organizational Change Management, 20(6), 761-773. https://doi.org/10.1108/09534810710831000

Jordan, P. J., Werner, A., \& Venter, D. (2015). Achieving excellence in private intensive care units: The effect of transformational leadership and organisational culture on organisational change outcomes. SA Journal of Human Resource Management, 13(1), 1-10. https://doi.org/10.4102/sajhrm.v13i1.707

Jørgensen, H. H., Owen, L., \& Neus, A. (2008). Making Change Work-Continuing the Enterprise of the Future Conversation. IBM Institute for Business Value. Retrieved from www-935.ibm.com/services/us/gbs/bus/pdf/gbe03100-usen-03-making-change-work.pdf

Judge, T. A., Piccolo, R. F., \& Ilies, R. (2004). The forgotten ones? The validity of consideration and initiating structure in leadership research. Journal of applied psychology, 89(1), 36-51. https://doi.org/10.1037/0021-9010.89.1.36

Kimber, M., Barwick, M., \& Fearing, G. (2012). Becoming an evidence-based service provider: staff perceptions and experiences of organizational change. The journal of behavioral health services \& research, 39(3), 314-332. https://doi.org/10.1007/s11414-012-9276-0.

Kirkpatrick, S. A., \& Locke, E. A. (1996). Direct and indirect effects of three core charismatic leadership components on performance and attitudes. Journal of applied psychology, 81(1), 36-51. https://doi.org/10.1037/0021-9010.81.1.36

Kuipers, B. S., Higgs, M., Kickert, W., Tummers, L., Grandia, J., \& Van der Voet, J. (2014). The management of change in public organizations: A literature review. Public administration, 92(1), 1-20. https://doi.org/10.1111/padm.12040

Lee, J. (2005). Effects of leadership and leader-member exchange on commitment. Leadership \& Organization Development Journal, 26(8), 655-672. https://doi.org/10.1108/01437730510633728

Levy, P. (2006). Industrial / organizational psychology: Understanding the workplace (2nd ed.). Boston, MA: Houghton Mifflin Organization.

Lewis, L. K. (1999). Disseminating information and soliciting input during planned organizational change: 
Implementers' targets, sources, and channels for communicating. Management Communication Quarterly, 13(1), 43-75. https://doi.org/10.1177/0893318999131002

Lines, R., Selart, M., Espedal, B., \& Johansen, S. T. (2005). The production of trust during organizational change. Journal of Change Management, 5(2), 221-245. https://doi.org/10.1080=14697010500143555

Longo, F. (2007). Implementing managerial innovations in primary care: can we rank change drivers in complex adaptive organizations?. Health Care Management Review, 32(3), 213-225. https://doi.org/10.1097/01.HMR.0000281620.13116.ce

Martin, G. P., Sutton, E., Willars, J., \& Dixon-Woods, M. (2013). Frameworks for change in healthcare organisations: A formative evaluation of the NHS Change Model. Health services management research, 26(2-3), 65-75. https://doi.org/10.1177/0951484813511233

Miller, K. I., \& Monge, P. R. (1986). Participation, satisfaction, and productivity: A meta-analytic review. Academy of management Journal, 29(4), 727-753. https://doi.org/10.2307/255942

Miller, V. D., Johnson, J. R., \& Grau, J. (1994). Antecedents to willingness to participate in a planned organizational change. Journal of Applied Communication Research, 22, 59-80. https://doi.org/10.1080/00909889409365387

Ministry of Health. (2016). General Directorate of Statistics \& Information, Health Statistic Book. Riyadh (KSA): Ministry of Health. Retrieved from https://www.moh.gov.sa/en/Ministry/Statistics/book/Documents/Statistical-Yearbook-1437H.pdf. [Last accessed on 2017 Oct 11].

Moran, J. W. and Brightman, B. K. (2001) 'Leading organizational change', Career Development International, 6(2), 111-118.

Northouse, P. G. (1997). Leadership: Theory and practice (2nd ed.). Thousand Oaks, CA: Sage.

Nunnally, J. C. (1978). Psychometric theory (2nd ed.). New York: McGraw-Hill.

Oreg, S. (2006). Personality, context, and resistance to organizational change. European journal of work and organizational psychology, 15(1), 73-101. https://doi.org/10.2224/sbp.2012.40.5.735

Packard, T., Patti, R., Daly, D., \& Tucker-Tatlow, J. (2012). Organizational change for services integration in public human service organizations: Experiences in seven counties. Journal of health and human services administration, 34(4), 471-525.

Pallant, J. (2013). SPSS survival manual (5th ed.). UK: McGraw-Hill Education.

Parry, K., \& Proctor-Thomson, S. (2003). Leadership, culture and performance: The case of the New Zealand public sector. Journal of Change Management, 3(4), 376-399. https://doi.org/10.1080/714023843

Qian, Y., \& Daniels, T. D. (2008). A communication model of employee cynicism toward organizational change. Corporate Communications: An International Journal, 13(3), 319-332. https://doi.org/10.1108/13563280810893689

Rafferty, A. E., \& Griffin, M. A. (2006). Perceptions of organizational change: A stress and coping perspective. Journal of applied psychology, 91(5), 1154-1162. https://doi.org/10.1037/0021-9010.91.5.1154

Rafferty, A. E., \& Griffin, M. A. (2006). Refining individualized consideration: Distinguishing developmental leadershipand supportive leadership. Journal of occupational and organizational psychology, 79(1), 37-61. https://doi.org/10.1348/096317905X36731

Rafferty, A. E., \& Restubog, S. L. D. (2010). The impact of change process and context on change reactions and turnover during a merger. Journal of Management, 36(5), 1309-1338. https://doi.org/10.1177/0149206309341480

Ridder, H. G., Doege, V., \& Martini, S. (2007). Differences in the Implementation of Diagnosis - Related Groups across Clinical Departments: A German Hospital Case Study. Health services research, 42(6), 2120-2139. https://doi.org/10.1111/j.1475-6773.2007.00723.x

Robbins, S. P., \& Judge, T. A. (2007). Organizational Behavior (12th ed.). Upper Saddle River, NJ Prentice Hall.

Sagie, A., Elizur, D., \& Koslowsky, M. (1995). Decision type, participative decision making (PDM), and organizational behavior: An experimental simulation. Human Performance, 8(2), 81-94. https://doi.org/10.1080/08959289509539858 
Schriesheim, C. A., Neider, L. L., \& Scandura, T. A. (1998). Delegation and leader-member exchange: Main effects, moderators, and measurement issues. Academy of Management Journal, 41(3), 298-318. https://doi.org/10.2307/256909

Schuller, K. A., Kash, B. A., Edwardson, N., \& Gamm, L. D. (2013). Enabling and disabling factors in implementation of Studer Group's Evidence-Based Leadership initiative: a qualitative case study. Journal of Communication in Healthcare, 6(2), 90-99. https://doi.org/10.1179/1753807613Y.0000000033

Schweiger, D. M., \& Denisi, A. S. (1991). Communication with employees following a merger: A longitudinal field experiment. Academy of management journal, 34(1), 110-135. https://doi.org/10.2307/256304

Shah, N. (2011). A study of the relationship between organisational justice and employee readiness for change. Journal of Enterprise Information Management, 24(3), 224-236. https://doi.org/10.1108/17410391111122835

Shum, P., Bove, L., \& Auh, S. (2008). Employees' affective commitment to change: The key to successful CRM implementation. European journal of marketing, 42(11/12), 1346-1371. https://doi.org/10.1108/03090560810903709

Singh, R., Mathiassen, L., Stachura, M. E., \& Astapova, E. V. (2010). Sustainable rural telehealth innovation: a public health case study. Health Services Research, 45(4), 985-1004. https://doi.org/10.1111/j.1475-6773.2010.01116.x

Smollan, R. K. (2015). Causes of stress before, during and after organizational change: a qualitative study. Journal of Organizational Change Management, 28(2), 301-314. Available from: https://doi.org/10.1108/jocm-03-2014-0055

Tabernero, C., Chambel, M. J., Curral, L., \& Arana, J. M. (2009). The role of task-oriented versus relationship-oriented leadership on normative contract and group performance. Social Behavior and Personality: an international journal, 37(10), 1391-1404. https://doi.org/10.2224/sbp.2009.37.10.1391

The government of Saudi Arabia. (2016a). Saudi Vision 2030. Retrieved from http://vision2030.gov.sa/sites/default/files/report/Saudi_Vision2030_EN_0.pdf

The government of Saudi Arabia.(2016b). National transformation program 2020. Retrieved from http://vision2030.gov.sa/sites/default/files/NTP_En.pdf

The Saudi Arabian General Investment Authority. (2016, September). Healthcare and life sciences opportunities. Retrieved from https://www.sagia.gov.sa/en/InvestorServices/InvestorLibrary/SubCategory_Library/Invest $\% 20$ Saudi\%20H ealthcare\%20Brochure\%20V161001.pdf

Tucker, A. L., \& Edmondson, A. C. (2003). Why hospitals don't learn from failures: Organizational and psychological dynamics that inhibit system change. California management review, 45(2), 55-72. https://doi.org/10.2307/41166165

Van Dam, K., Oreg, S., \& Schyns, B. (2008). Daily work contexts and resistance to organisational change: The role of leader-member exchange, development climate, and change process characteristics. Applied psychology, 57(2), 313-334. https://doi.org/10.1111/j.1464-0597.2007.00311.x

Voelpel, S. C., Leibold, M., \& Mahmoud, K. M. (2004). The organizational fitness navigator: enabling and measuring organizational fitness for rapid change. Journal of change management, 4(2), 123-140. https://doi.org/10.1080/14697010410001687483

Wanberg, C. R., \& Banas, J. T. (2000). Predictors and outcomes of openness to changes in a reorganizing workplace. Journal of applied psychology, 85(1), 132-142. https://doi.org/10.1037/0021-9010.85.1.132

Watson, C., \& Hoffman, L. R. (2004). The role of task-related behavior in the emergence of leaders: The dilemma of the informed woman. Group \& Organization Management, 29(6), 659-685. https://doi.org/10.1177/1059601103254263

Yamane, T. (1967). Statistics: An Introductory Analysis (2nd ed.). New York: Harper and Row.

Yukl, G. (1999). An evaluative essay on current conceptions of effective leadership. European Journal of Work and Organizational Psychology, 8(1), 33-48. https://doi.org/10.1080/135943299398429.

Yukl, G. (2008). How leaders influence organizational effectiveness. The leadership quarterly, 19(6), 708-722. https://doi.org/10.1016/j.leaqua.2008.09.008 
Yukl, G. A. (2006). Leadership in Organizations (6th ed.). Upper Saddle River, NJ: Pearson/Prentice Hall.

Yukl, G., Gordon, A., \& Taber, T. (2002). A hierarchical taxonomy of leadership behavior: Integrating a half century of behavior research. Journal of Leadership \& Organizational Studies, 9(1), 15-32. https://doi.org/10.1177/107179190200900102

\section{Copyrights}

Copyright for this article is retained by the author(s), with first publication rights granted to the journal.

This is an open-access article distributed under the terms and conditions of the Creative Commons Attribution license (http://creativecommons.org/licenses/by/4.0/). 